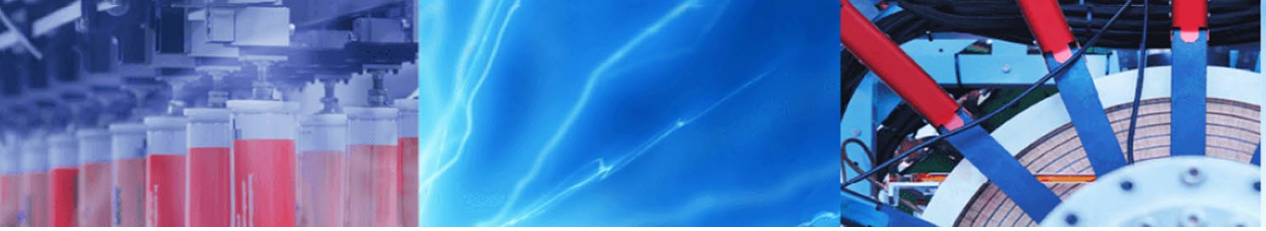

Research Article

\title{
Coupling groundwater GIS mapping and geovisualisation techniques in urban hydrogeomorphology: focus on methodology
}

\author{
Liliana Freitas $^{1}$ (D) Helder I. Chaminé ${ }^{1,2}$ (D) Alcides J. S. C. Pereira ${ }^{3}$ (D)
}

(c) Springer Nature Switzerland AG 2019

\begin{abstract}
The role of climate, geology, geomorphology, land use/cover, hydraulics and human activities are vital for the balanced and integrated assessment of water resources in urban areas. This approach addresses the key importance on ground field surveys at several scales, a representative hydrological inventory and an integrated groundwater mapping as useful tools to support urban groundwater systems conceptualisation. Lately, a new emphasis has arisen, addressing issues related to an integrated geovisualisation techniques and Geographical Information System (GIS) mapping studies on urban water supply systems, mainly in historical cities. Some key catchments in Porto urban area (NW Portugal) was selected to demonstrate this approach and to show the importance of groundwater GIS mapping for urban studies. The Porto city bedrock is dominated by an anisotropic and heterogeneous fissured media. An extensive field survey yielded data on hydroclimatology, hydrogeology, hydrogeomorphology, urban hydraulics and potential contamination sources. The Infiltration Potential Index in Urban Areas (IPI-Urban), Urban Recharge and Vulnerability Indexes was determined using GIS mapping techniques and hydrological inventory fieldwork. The integrated approach can be incorporated into an urban hydrological management system to support decision making on sustainable groundwater resources and in urban planning.
\end{abstract}

Keywords Urban groundwater · GIS mapping · Urban hydrogeomorphology · IPI-Urban · Conceptual site model

\section{Introduction}

In nature, urban groundwater drives many geological, geomorphic, geochemical, ecotoxicological and hydraulic processes, sustaining several ecological purposes and services. Groundwater is the largest accumulation of fresh water and represents $98 \%$ of the Earth's unfrozen freshwater resources (e.g. [41, 42, 46, 51, 52]).

Gilbrich and Struckmeier [38] bring up an important issue: 'Before the middle of the past century the increasing demand for water, particularly in the industrialised countries, called for a rational planning of water resources. Hydrogeological maps were considered useful basic documents in this development and, consequently, compilation of hydrogeological maps at various scales and for various purposes.... Urban groundwater maps are of key importance in field data synthesis and communication related to several fields, such as geomatic techniques, applied geosciences, urban hydrogeology, hydraulics and sanitation, planning/land use and urban heritage. That approach is the source for the key role of the urban maps in a dual outlook focused on their main purposes and on their end-users (e.g. [17, 21, 22, 38, 60]). Consequently, an urban water framework consists not only of sustainable technical-scientific studies but also socio-economic, cultural, heritage and ethical challenges (e.g. [19, 20, 35, 39]).

$\triangle$ Liliana Freitas, Ifsfr@isep.ipp.pt; Helder I. Chaminé, hic@isep.ipp.pt; Alcides J. S. C. Pereira, apereira@dct.uc.pt | ${ }^{1}$ Laboratory of Cartography and Applied Geology (LABCARGA), Department of Geotechnical Engineering, School of Engineering (ISEP), Porto, Portugal. ${ }^{2}$ Centre GeoBioTec|UA, Aveiro, Portugal. ${ }^{3}$ CITEUC, Department of Earth Sciences, Faculty of Sciences and Technology, University of Coimbra, Coimbra, Portugal.

SN Applied Sciences (2019) 1:490 | https://doi.org/10.1007/s42452-019-0519-z 
As discussed in Chaminé et al. [21], hydrogeological and groundwater maps at several scales (mostly, large scale to local and regional scales) are created by practitioners and/or researchers for the exploration, description and evaluation of water resources, as well as to support detailed descriptions at the site investigation level. In addition, groundwaterrelated tasks (e.g., hydrogeological inventory, vulnerability issues, identification of potential contamination areas and wellhead protection sites, water well drilling and conceptual site models, among others) are significantly improved by terrain mapping methods, including unmanned aerial vehicles (UAV), remote sensing, high-resolution photogrammetry, geographic information systems (GIS), global position systems (GPS), and geovisualisation techniques (e.g. [18, 21, $22,32,48,61])$. In addition, groundwater maps are a reliable approach to illustrate quantification of the urban recharge/ discharge (e.g. [37, 49, 55, 58, 65, 69]).

Hydrogeomorphology is a major interdisciplinary and multidisciplinary field, which encompasses climatology, geomorphology, geology and hydrology studies, among others (e.g. [10, 26, 61-64]). Urban hydrogeomorphology is an emerging field and operates in a multidisciplinary framework focused on a comprehensive understanding of urban hydrologic processes (including hydraulics and sanitation) and the interaction of geomorphic processes related to the surface water/groundwater flow regime.

In this study, we present a methodological GIS-based mapping approach for the assessment of urban groundwater systems focused on vulnerability, infiltration and recharge. To illustrate that approach two catchments in the Porto urban area (NW Portugal) were selected. This approach was based on geovisualisation and GIS mapping techniques related to groundwater and applied geomorphology, combined with a groundwater inventory, potential contamination sources survey, and data on land cover/use and urban hydraulics and sanitation features. The relationships with surface and subsurface hydrology were highlighted, as well as the effects of climate, geomorphology and geology. Urban groundwater mapping and several derived thematic maps were created in order to outline an integrated vulnerability assessment of groundwater resources. In addition, that approach addresses key information to define the urban potential infiltration index (IPI-Urban) and urban recharge/ discharge areas. This multi-technique mapping approach plays an important role in the development of a hydrogeological conceptual site model in urban areas.

\section{Background of the studied area: Porto urban area}

The Porto metropolitan region is the second most populated area in mainland Portugal and supports over 1.2 million inhabitants. The city of Porto has an area of $41.3 \mathrm{~km}^{2}$ with a population of 237,559 inhabitants [43]. Vila Nova de Gaia urban area is located on the left embankment of the Douro River and it is one of the largest cities in Portugal, with a continuous need for urban development and expansion.

Porto and Vila Nova de Gaia are surrounded by an outstanding urban and natural landscape. These urban areas were shaped on the granitic hillsides near the Douro River during the development of the Kingdom of Portugal in the 12 th century $[16,28]$. Earlier settlements on these sites date back to the early 5 th century $B C$, since the days of Visigoths and Suevians. During the 1 st century BC Roman and then Moorish occupation of the Iberian Peninsula took place, but they were evicted definitively in $A D$ 868, after which the area remained a Christian land and Portuguese sovereignty was established in 1143 [29]. In 1996 , the architectural and historical attributes of the old neighbourhoods in downtown Porto were recognised by UNESCO as a World Heritage Site.

The geotectonic background of the Porto and Gaia region includes a crystalline fissured basement of highly deformed and overthrust Late Proterozoic/Palaeozoic metasedimentary and granitic rocks. The bedrock is mostly composed of phyllites, micaschists, gneisses and granitic rocks, while post-Miocene alluvial and Quaternary marine deposits dominate the sedimentary cover (e.g. [1-4, 6, 23, 24]; and references therein). The granitic rocks are often weathered to different grades, altering randomly from fresh granitic boulder to residual soil, showing highly variable conditions, resulting in arenisation and kaolinisation, which may reach depths over $25 \mathrm{~m}$ (e.g. [11, 14, 23, 27]).

The Porto and Vila Nova de Gaia cities were constructed along the rocky hillsides divided by the Douro river. The regional morphology framework is a littoral platform with a regular planation surface dipping gently to the West. The Douro riverside downtown was established in a steepwalled valley with sharp and high slopes $[23,35,36]$. The drainage network highlights the regional tectonic lineament systems (typically NNW-SSE, NE-SW, ENE-WSW). Freitas et al. [35] pointed out that the flattened surfaces of higher altitude (130-160 $\mathrm{m}$ a.s.l.) occur in the eastern part of the urban area, enclosed by smaller flattened surfaces of lower altitudes (80-125 $\mathrm{m}$ a.s.l.). The lowest level surfaces $(<25 \mathrm{~m})$ are found in valley bottoms in the western sector.

Afonso et al. [1-4] states the Porto region is dominated by a fissured crystalline bedrock, including diverse 
hydrogeological media such as overlying sediments, weathered rocks, weathered-fissured zones, and fractured hard-rock substratum. According to Freitas et al. [36] the Porto urban area is characterised by a moderate to low infiltration potential, the urban groundwater recharge rate is less than $8 \%$, and shallow aquifer potential yields are very low $\left(<0.13 \mathrm{~L} / \mathrm{s} / \mathrm{km}^{2}\right)$. Table 1 and Fig. 1 shows the general hydrogeological framework of the studied urban area.

\section{Groundwater GIS mapping for urban areas: techniques and methodology}

Additional issues in water resources sustainability and hydrological cycle comprehension are added by urbanisation. Usually the anatomy of an urban underground is constituted by an intricate network of pipes, conduits, channels, galleries, storm sewers and other structures that serve to change the hydraulic conductivity of the geomaterials (e.g. $[7,9,12,21,40,72])$. Consequently, these urban buried features act as favourable pathways for the flow of urban-sourced contaminants into underlying water resources. In addition, the surface is generally covered and perceived as almost impervious (e.g. building, asphalt, concrete, brick, etc.). Nowadays, environmental pressures are affecting urban groundwater systems which are faced with increasing urban pressure, overexploitation, contamination/pollution issues and climate variability.

Figure 2 presents a flowchart of the GIS mapping methodology to assess a hydrogeological conceptual model in urban areas focused on an integrative approach. The assessment was performed in two urban catchment basins of Porto city using GIS mapping technology. ESRI ArcGIS Desktop software was used for map data visualisation, overlay analysis and layout creation. All overlay analysis was performed using a raster file format, with a pixel resolution of $5 \times 5 \mathrm{~m}$. The 3D urban hydrogeological site conceptual model conceptual model was built using ArcGIS Pro and OCAD for Cartography 11. The coordinate system of the basic data is ETRS-1989-Portugal-TM06.

In order to design the urban hydrogeological conceptual model several steps were followed, such as: collection of basic hydrological data, evaluation of intrinsic vulnerability, computation of the Urban Potential Infiltration Index (IPI-Urban) and evaluation of recharge/discharge.

Currently, the urban groundwater conceptual site models are an impressive tool to support sustainable water resources exploration, abstraction and or management for urban areas (Fig. 3). Maps are an invaluable way for presentation and communication with practitioners, researchers, water-related professionals and society. Indeed, cartographic reasoning, geovisualisation techniques and urban groundwater mapping are remarkable tools for supporting a full-scale integrated data analysis of reciprocal global actions, as well as to address local concerns, thus contributing to balanced urban sustainable water resources characterisation, evaluation, protection, management and governance [21, 22].

The collection of the basic hydrological data carries great importance in this approach, and it resulted in a large amount of information, such as topography, land use, geology, morphotectonics, hydrogeological features, hydroclimatology, net recharge, urban hydraulics and sanitation. In addition, other data collected in the field surveys, namely a hydrogeological inventory (Fig. 4) and potential contamination activities inventory. A geo-database was also created to collect, organise and analyse the spatial data. In the fieldwork mapping special equipment was used for measuring the groundwater quality parameters (temperature, $\mathrm{pH}$ and electrical conductivity) with a portable multiparameter meter (Hanna HI-9828) and for georeferencing over 290 hydrogeological sites with a highaccuracy GPS device (Trimble Geo-Explorer).

The Zaporozec [74] classification of potential contamination activities was applied and a field inventory datasheet was designed. The potential contamination activities were classified in categories by its source of origin [70, 71]: urbanisation, industry, agriculture, water mismanagement and miscellaneous.

The evaluation of vulnerability was performed using several indexes, namely DRASTIC [5], DRASTIC-fm [30], GODS [34], SINTACS [25] and SI [56]. The hydrogeological background was the basis of the vulnerability assessment, and the international colour code of the DRASTIC index was used. For SINTACS, the weights of severe and fissured strings were used for the SINTACS index [25]. The severe string was applied in areas that are simultaneously sedimentary cover/saprolite and in the land-use (LU) categories "urban fabric" or "industrial, commercial and transport units". The fissured string was applied where metasedimentary, granitic and gneissic rocks match with the LU classes "green urban areas", "forest and natural/ semi-natural areas" and "agricultural areas". The LU parameter (Land Use) was considered in the calculation of the SI index [31]. In order to achieve the urban groundwater mapping assessment, an evaluation integrating all the methods was performed.

The Infiltration Potential Index in Urban Areas (IPIUrban) considers eight factors, and they were revised and updated from the key literature (e.g. [3, 4, 36, 44, 45, 61, $62,73]$, and references therein). The Analytical Hierarchy Process (AHP) was used to achieve the weight for each factor. It consists in using pairwise evaluation between the factors, comparing all the criteria to one another, evaluating the rate or the weight of each factor describing the 


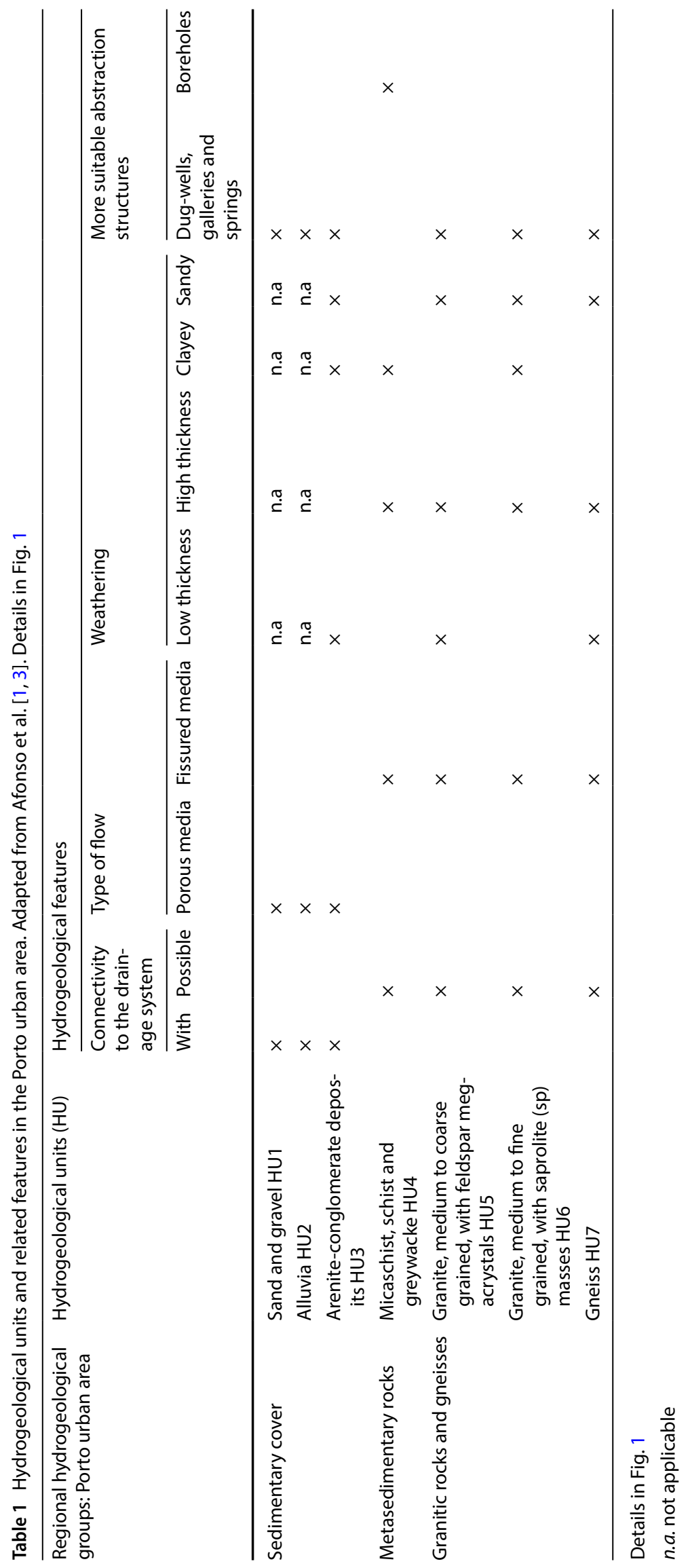



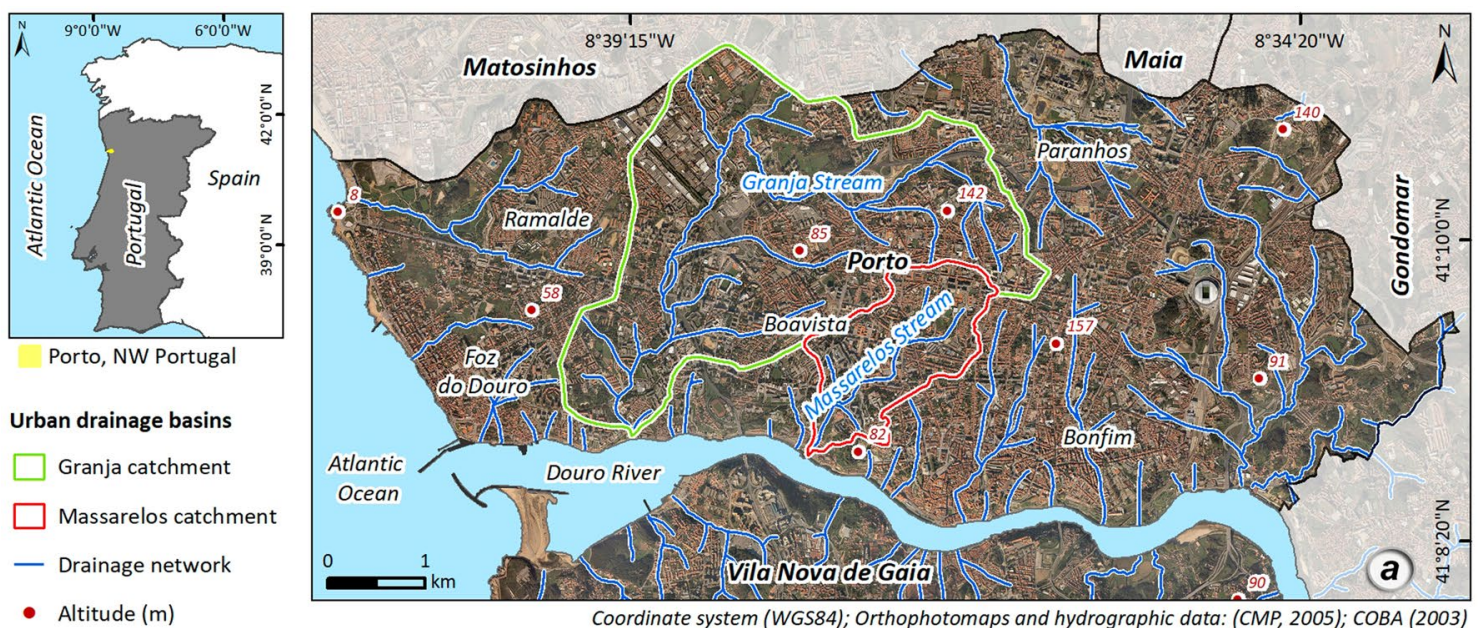

Hydrogeological Units (HU)

$\square$ Sands and gravels - HU 1

Alluvia (ancient waste

4 disposal, wd) - HU 2

Clayey arenite-conglomerate

deposits - HU 3

Micaschists, schists and

graywackes - HU 4

Granite, medium to coarse

- grained, with feldspar

megacrystals - HU 5

Granite, medium to fine

5 grained, with saprolite (sp)

masses - HU 6

$\square$ Gneisses - HU 7

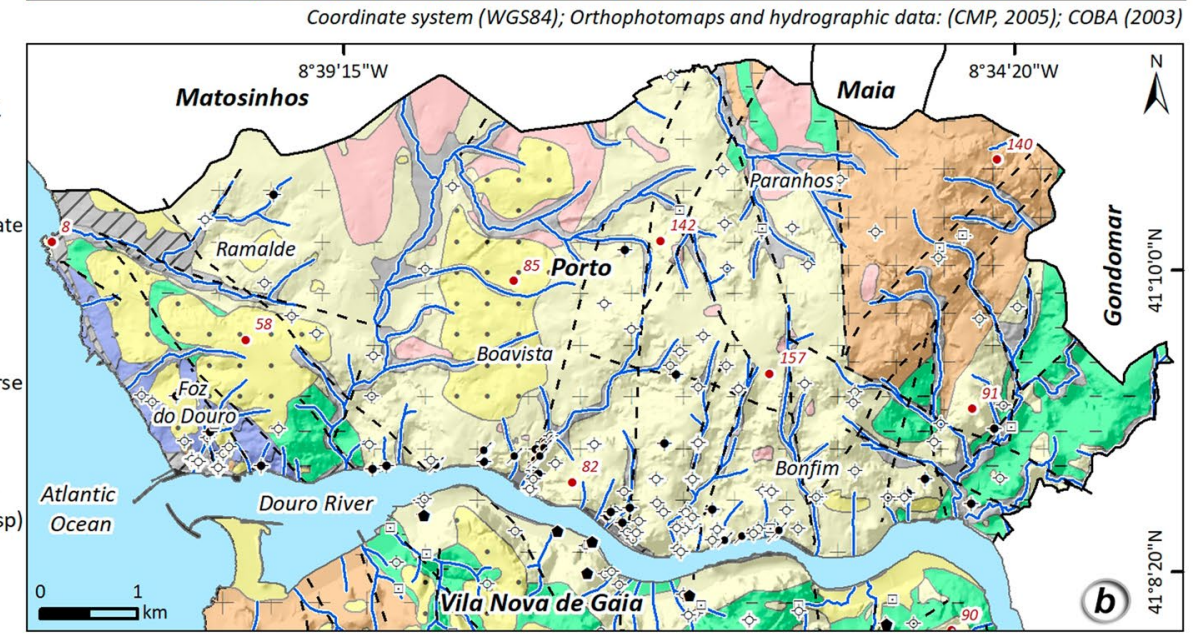

\section{Geomorphology \\ - Top \\ - - Base \\ ـ Gully (Douro Valley) \\ - Fault scarp \\ - Tectonic lineaments}

Urban Infiltration Potential Index (IPI-URBAN)

Very high (80 -100)

High (60 - 80)

$\square$ Low to Moderate (40 - 60)

$\square$ Very low to Low (20 - 40)

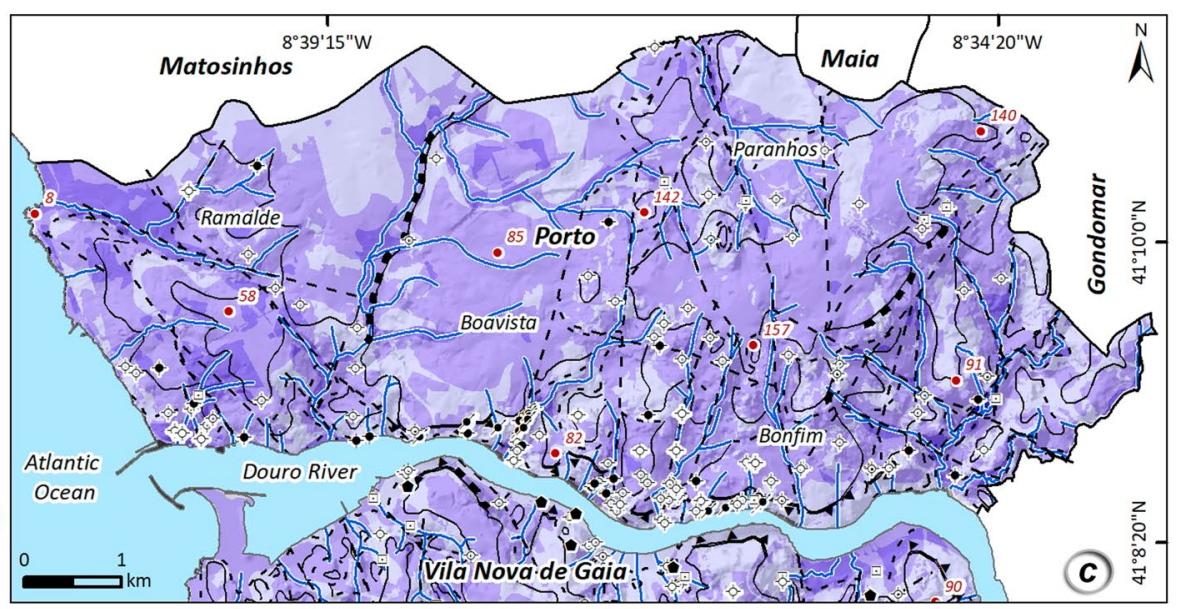

Groundwater inventory

- Spring \&pring/fountain \& Fountain W Washing places Water mine

Fig. 1 Porto urban area setting (NW Portugal): a general background of the urban area and drainage network; $\mathbf{b}$ hydrogeological setting (adapted from [1, 4]; details in Table 1; c hydrogeomorphological mapping and IPI-Urban. Adapted from Freitas et al. [36] 
Fig. 2 Conceptual flowchart of the GIS-based methodology for the urban groundwater assessment

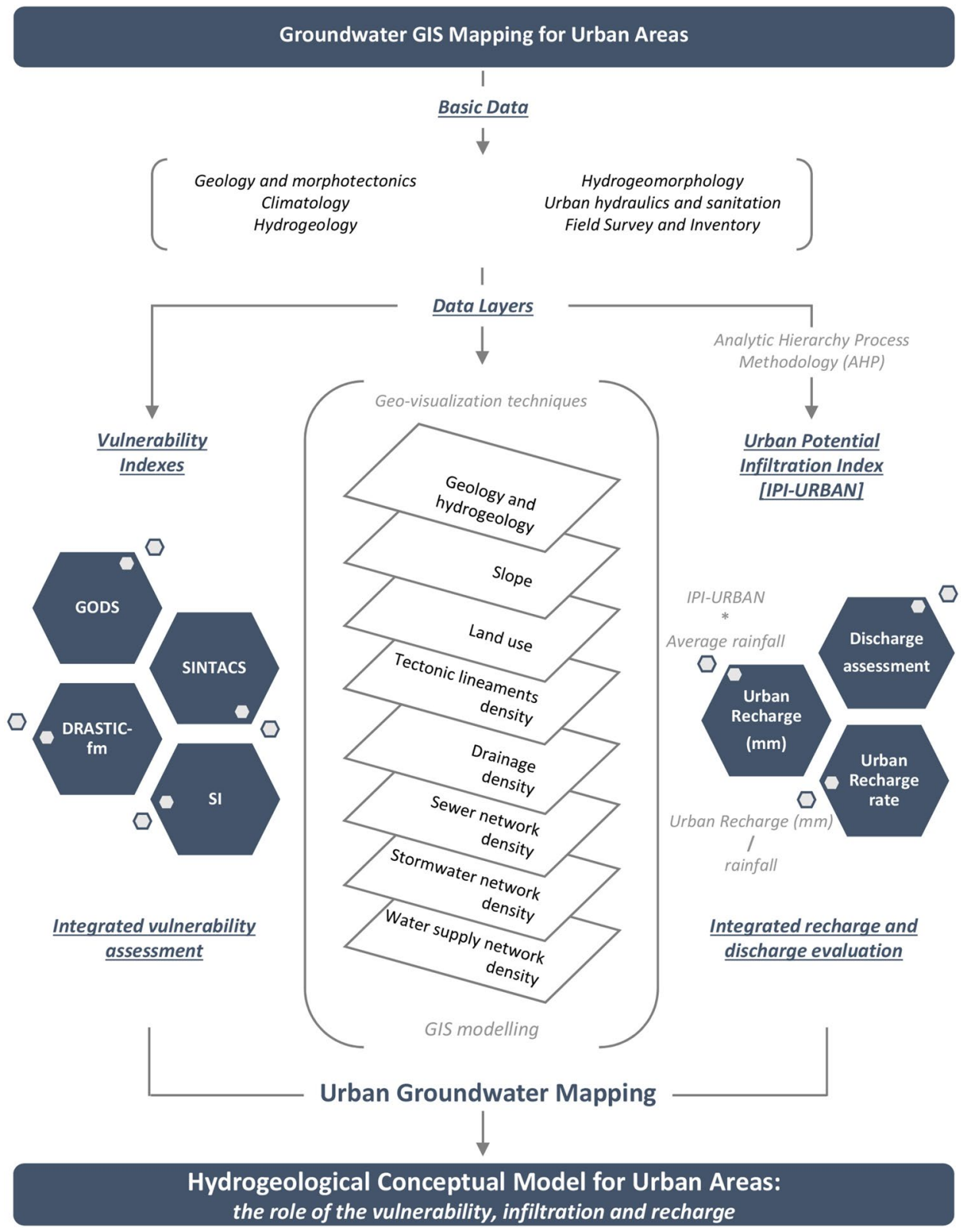

importance of each of these factors in the final analysis (e.g. $[8,15,47,50,53,57,59])$. The information collected during fieldwork was very important in obtaining the specific weights attributed to each factor.

The maps to calculate the Infiltration Potential Index in Urban Areas (IPI-Urban) are related to: (1) geology and morphotectonics; (2) climate and hydrology; (3) urban hydrogeology and hydrogeomorphology; (4) urban hydraulics and sanitation. IPI-Urban is a weighted sum of eight factors, namely: hydrogeological units, tectonic lineament density, land use, drainage density, slope, sewer network density, stormwater network density and water supply network. Urban hydraulic sanitation was included in the index based on the last three factors. The index represents the combination of all factors, ranging from 0 to 100. The higher values represent better conditions for water infiltration. The factors were represented and analysed in GIS and resulted in a raster (a grid with a pixel size of $5 \times 5 \mathrm{~m}$ ) showing the spatial variation of IPI-Urban values.

The weights of the factors are: hydrogeology $(25.1 \%)$; tectonic lineament density (16.2\%); land use (15.8\%); water supply network (13.2\%); slope (13.2\%); sewer network density (5.9\%); stormwater network density (5.9\%) and drainage network density (4.7\%). The combination between IPI-Urban and the urban geomorphological map yields the urban hydrogeomorphological map. 


\section{Urban Groundwater Conceptual Site Model}

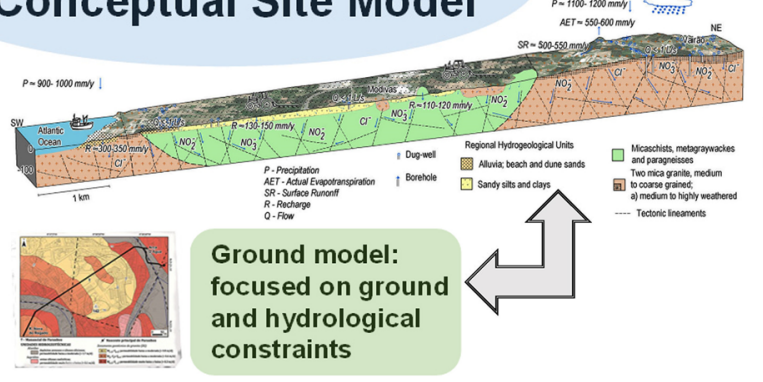

Urban field data + in situ and subsurface investigations (2D/3D/4D)

Ground mapping: remote sensing, terrain analysis, geology, morphotectonics, ...

Groundwater data: hydrogeological inventory surveys, hydrodynamics, hydrogeochemistry, isotopic hydrology, urban hydraulics, ...

Other techniques: hydroclimatology, hydrogeophysics, hydrogeomorphology, hydropedology, hydrogeotechnics, drilling, ...

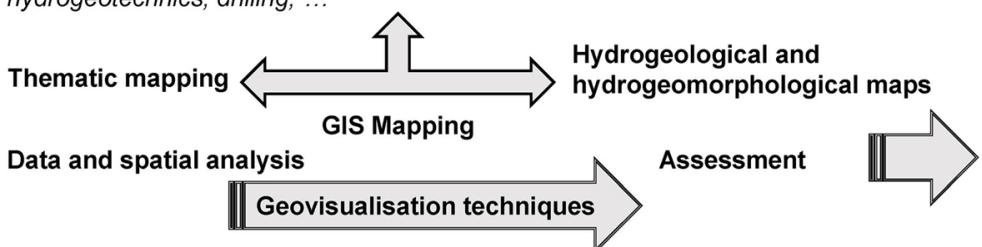

\section{Numerical model: \\ focused on \\ mathematical and \\ predictive scenarios}

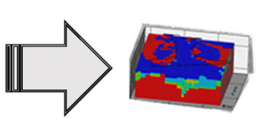
scenarios prediction

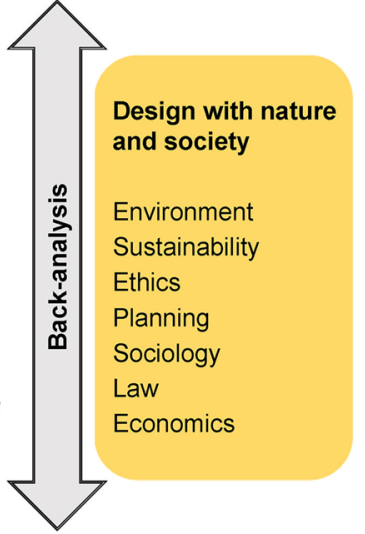

Multi-model approach for

Fig. 3 Urban Groundwater conceptual site model: the role of field surveys, mapping and related techniques. Adapted from Chaminé et al. [21]
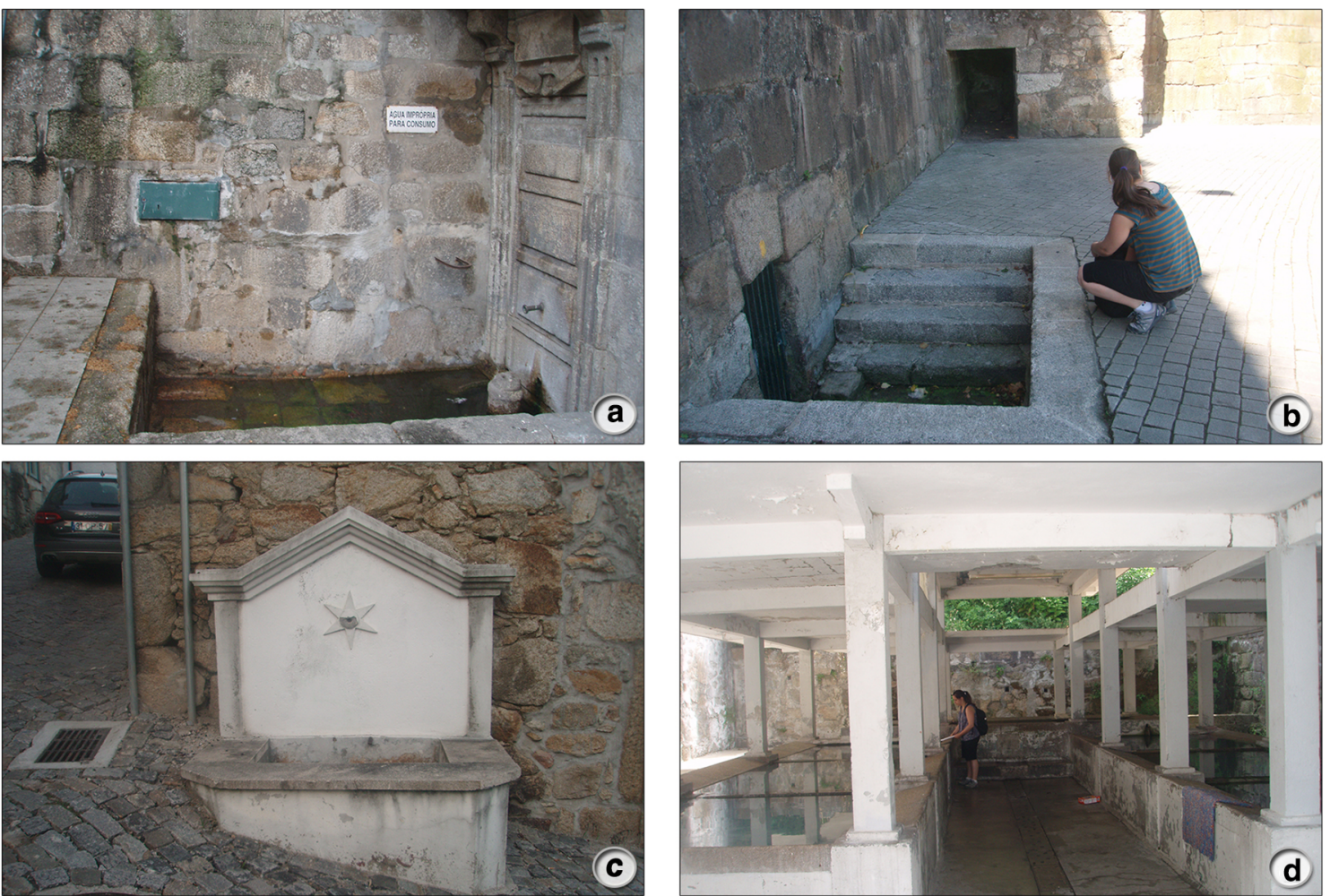

Fig. 4 Some aspects of the urban hydrogeological inventory surveys: fountain (a, c); water mine (b) and public washing place (d) 
The calculation of the urban recharge provides the analysis of the rainfall data. Regional hydrogeological studies in the surroundings of the study area suggest an initial urban recharge rate of $8 \%[1,3,4]$. In this study $1071.7 \mathrm{~mm}$ was considered as the average rainfall. The output results using GIS tools address the production of the urban recharge map and aquifer potential yields map (details in Fig. 5).

\section{Integrative urban mapping assessment: Massarelos and Ribeira da Granja sites}

\subsection{Urban vulnerability mapping}

Porto City is a densely urbanised area. To illustrate the role of urban groundwater mapping the urban catchment basins of Massarelos and Ribeira da Granja were selected. The gathered information was combined into a spatial database and a GIS platform.

In order to assess hydrogeological and groundwater potential contamination activities, several inventories were performed according to the described methodology. Figure 6 presents some aspects of relevant sites identified during the inventory of potential contamination activities. In the studied catchments, 264 groundwater potential contamination activities were found and inventoried. The concentration of these activities may contribute to an increase in groundwater contamination. The urban vulnerability assessment was performed using several indexes. On the main map, the groundwater potential contamination activities overlay the vulnerability maps.

The intrinsic vulnerability indexes show the following (details in Fig. 7):

1. Ribeira da Granja catchment area (1) The GODS index has four vulnerability categories: negligible, low-moderate, moderate to high. The majority of contamination sources (109) were included in the low-moderate category; (2) The DRASTIC-fm index classifies in lowmoderate, moderate, high to very high. The groundwater potential contamination activities are mostly in the high category; (3) The SINTACS index shows moderate, high and very high-extremely high categories. The majority of groundwater potential contamination activities (105) are related to the high category of vulnerability; (4) The SI index shows the categories very low-low, moderate-high, high to very high. The vulnerability category high is the one with the most occurrences of groundwater potential contamination activities (103).

2. Massarelos catchment area (1) In the GODS index, the groundwater potential contamination activities (60) were include in low-moderate category. (2) In the DRASTIC-fm most of the groundwater potential contamination activities fall into the high class; (3) In the SINTACS index, the majority of groundwater potential contamination activities (58) were included in high

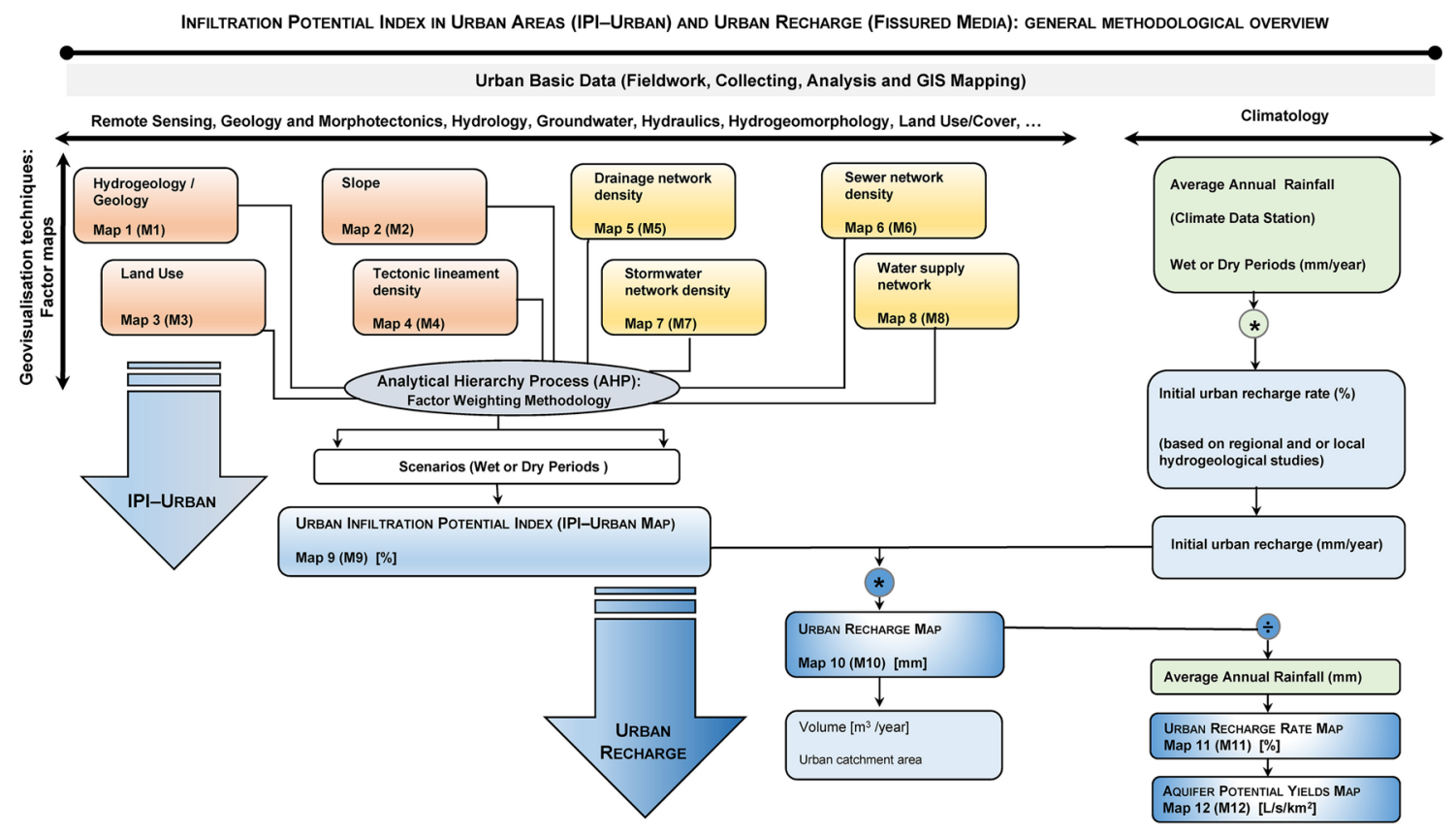

Fig. 5 Methodological overview to determine the Infiltration Potential Index in Urban Areas (IPI-Urban) and Urban Recharge in fissured media 

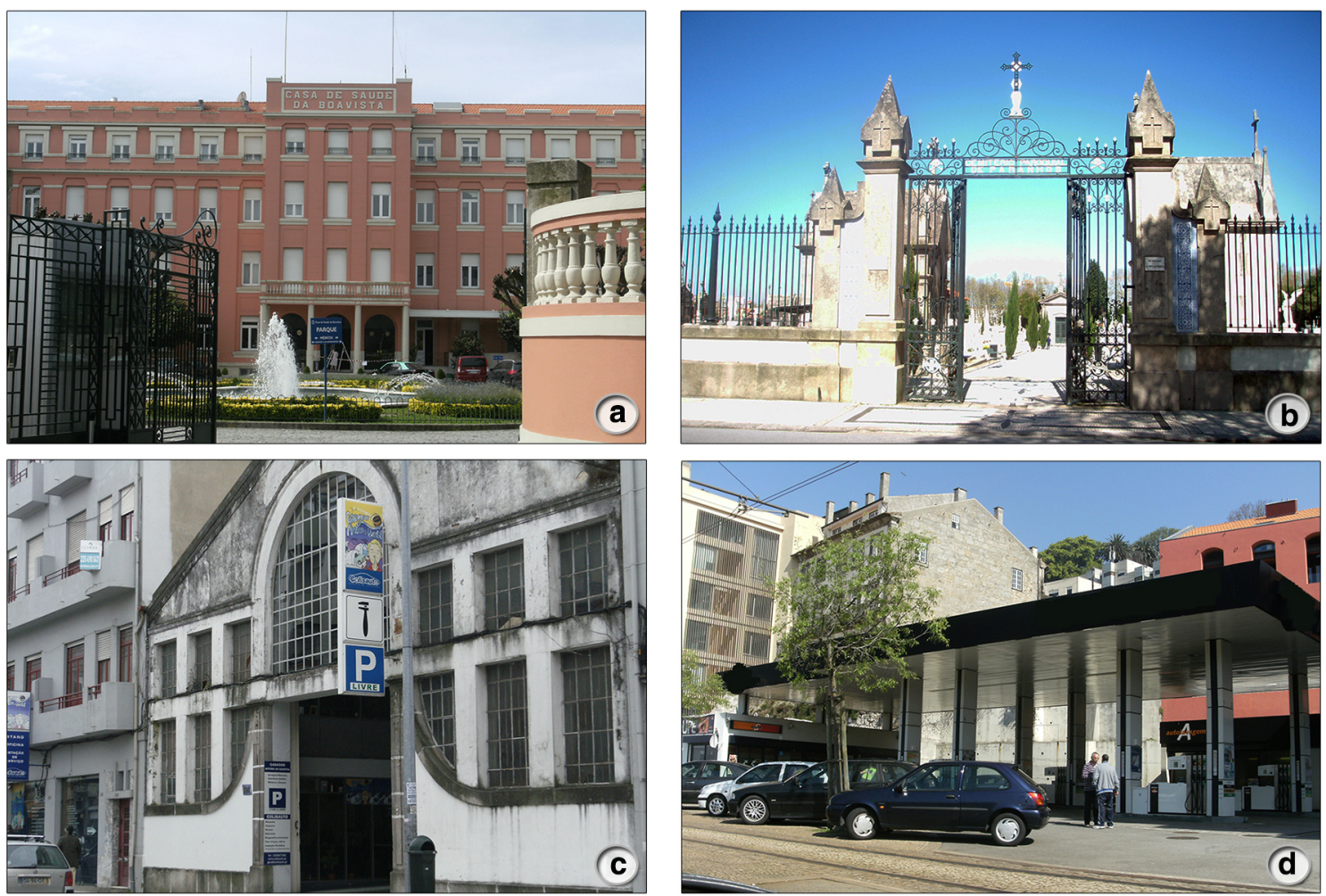

Fig. 6 Sites related to aspects of the field inventory of groundwater potential contamination activities: a hospital; b cemetery; c repair shop and $\mathbf{d}$ petrol station

class of vulnerability; (4) In the SI index, activities occur mostly in the moderate-high (26) and high (39) classes of vulnerability.

The Ribeira da Granja and Massarelos catchment basins include the following hydrogeological units (see the main map for details): sedimentary cover (HU2, HU3), metasedimentary rocks (HU4) and granitic rocks (HU6). The relationship between hydrogeological units (HU) and vulnerability indexes to groundwater contamination is shown in Fig. 8.

The GODS index roughly highlights the hydrogeological framework. Furthermore, the sedimentary cover category shows moderate to high vulnerability; the metasedimentary rocks displays low-moderate vulnerability, while on granitic rocks vulnerability is negligible. Supplementing this information with the DRASTIC-fm, SINTACS and SI indexes was crucial for a better assessment of the vulnerability, particularly to characterise the study areas according to its geological (fracture degree rock media- $\mathrm{fm}$ parameter) and urban (land use) features. Generally, it was found that more than one vulnerability category corresponds to each hydrogeological unit. According to the DRASTICfm index, HU2 and HU3 show high to very high vulnerability. Metasedimentary rocks and granitic rocks present vulnerability ranging from low-moderate to high. Using the SINTACS index, HU2 and HU3 are classified as having very high to extremely high vulnerability. For micaschists, schists and greywackes vulnerability ranges from low to moderate. Granitic rocks were considered moderate to high vulnerability. Finally, SI index shows higher vulnerability associated to alluvia and clayey arenite-conglomerate deposits. Metasedimentary rocks are classified from very low to moderate-high vulnerability, whereas granites range from low-moderate to high.

An integrative approach of the four vulnerability indexes is the correct and balanced way to assess the groundwater potential contamination GIS-based mapping. Clearly, each index has diverse performance according to the context. Hence DRASTIC-fm is more suitable for a fissured hard-rocks background, while SI considers the land use/cover features. The indexes applied individualise the several hydrogeological fissured crystalline media contexts. Finally, the porous media had the highest vulnerability classification according to all indexes.

\subsection{Urban infiltration and recharge potential zones}

The identification of the urban areas with potential groundwater infiltration reflects a comprehensive integrative approach of the climatologic, hydrologic, 


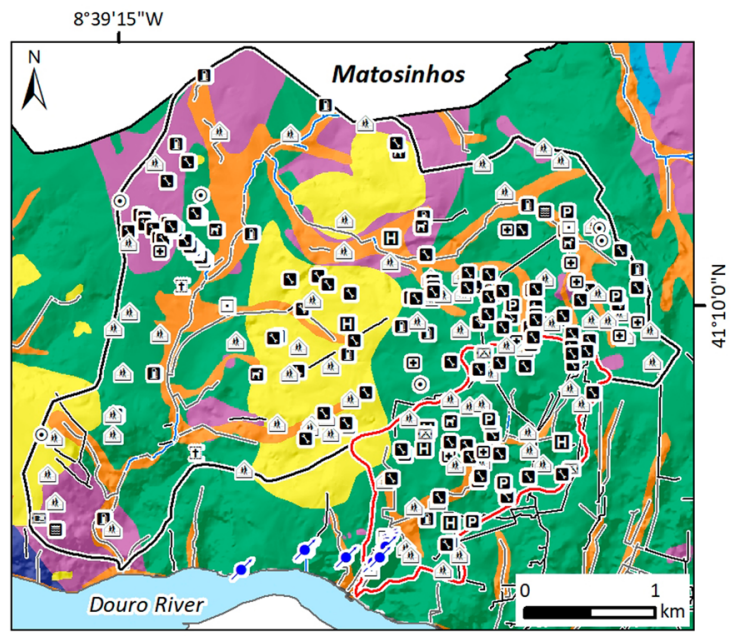

\section{GODS INDEX}

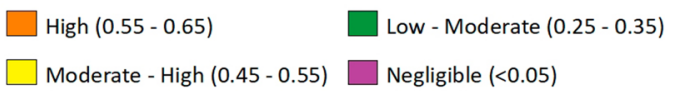

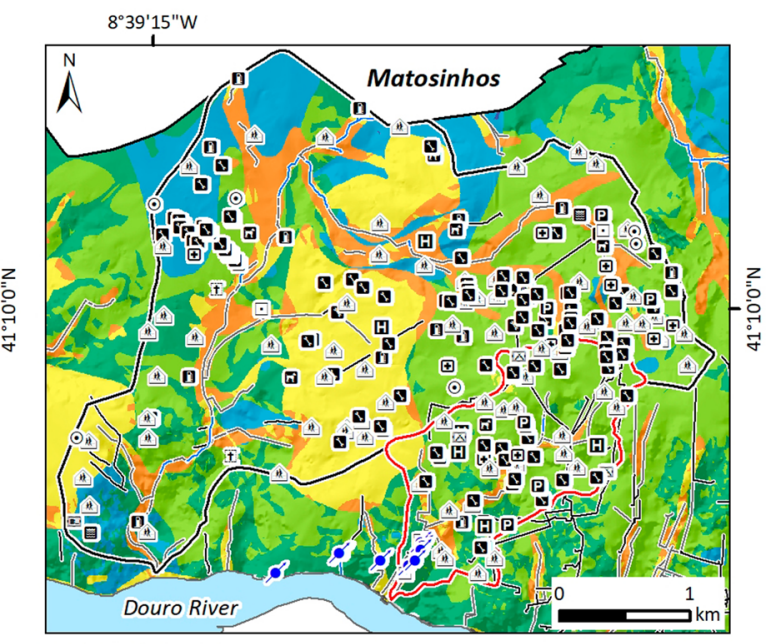

\section{DRASTIC-fm INDEX}

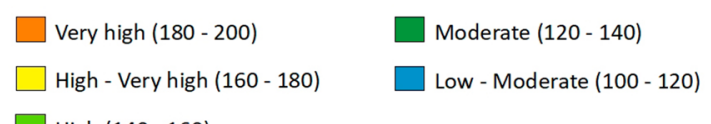

$\square$ High (140 - 160)

$8^{\circ} 39^{\prime} 15^{\prime \prime} \mathrm{W}$

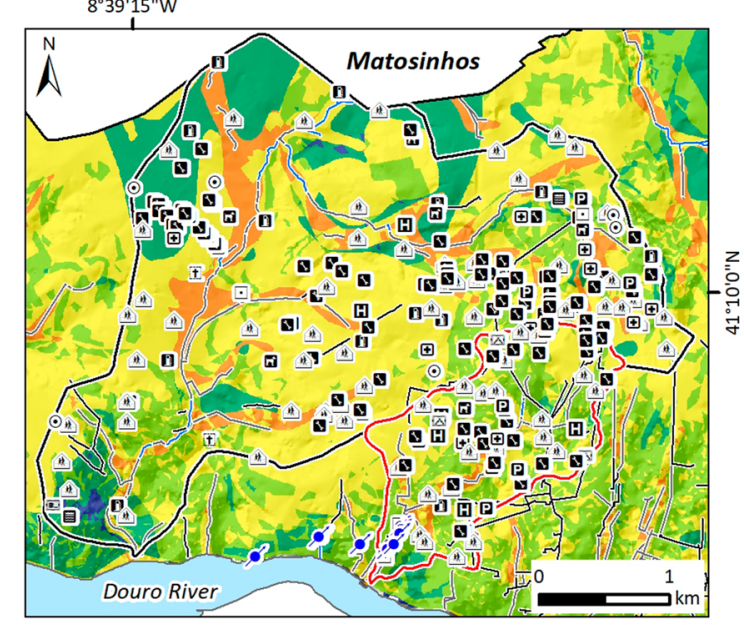

SI INDEX

$\square$ Very high (80 -90)
$\square$ High (70 - 80)
$\square$ Moderate - High $(60-70)$

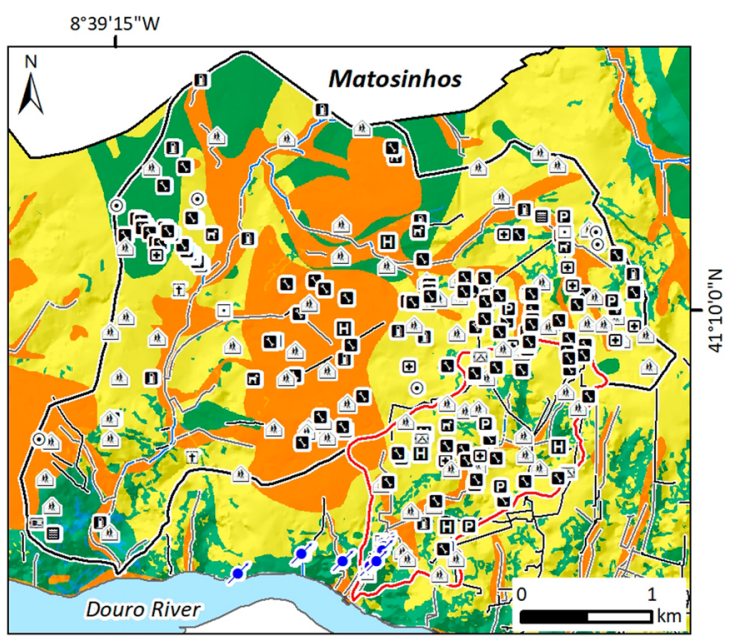

SINTACS INDEX

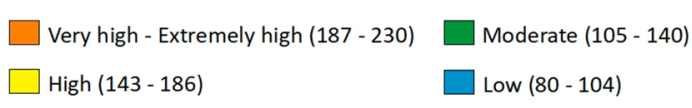

Groundwater potential contamination activities

\section{Urbanisation}

D Garage

$\boxplus$ Healthcare unit

H Hospital

Detrol station

๑ Public washing place

1. Repair shop

\begin{abstract}
低 School/University
\end{abstract}
(I) Veterinary clinic

Industry

Municipal wastewater

Water mismanagement

$\odot$ Active dug-well
숬 Artificial lagoon

- Canalised water course

Miscelaneous

[† Cemetery

圆 Kennel/Cattery

¿ Military facilities

$\square$ Granja catchment

\section{Surface water}

— Water course

Groundwater

- Spring

_ Underground spring water gallery

Massarelos catchment

Fig. 7 Urban groundwater vulnerability assessment in catchment basins of Ribeira da Granja and Massarelos (Porto city, NW Portugal): GODS; DRASTIC-fm; SINTACS and SI 


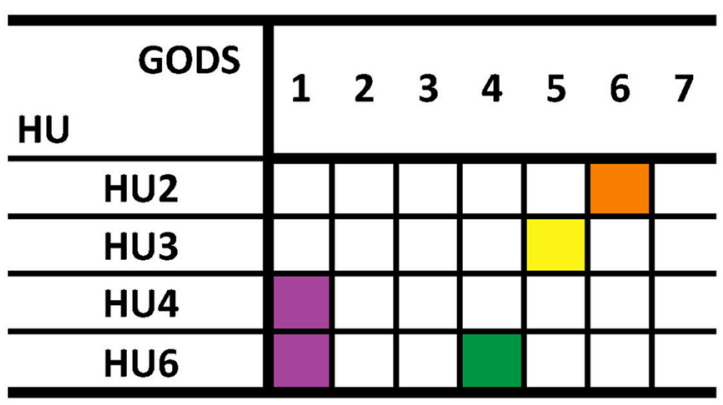

1- Negligible; 2- Negligible-Low; 3- Low; 4Low-Moderate; 5 Moderate-High; 6- High; 7Extreme

\begin{tabular}{|c|c|c|}
\hline${ }_{\text {HU }}$ SINTACS & 12 & \\
\hline HU2 & & \\
\hline HU3 & & \\
\hline HU4 & & \\
\hline HU6 & & \\
\hline
\end{tabular}

1- Low; 2- Moderate; 3- High; 4-

Very high-Extremely high

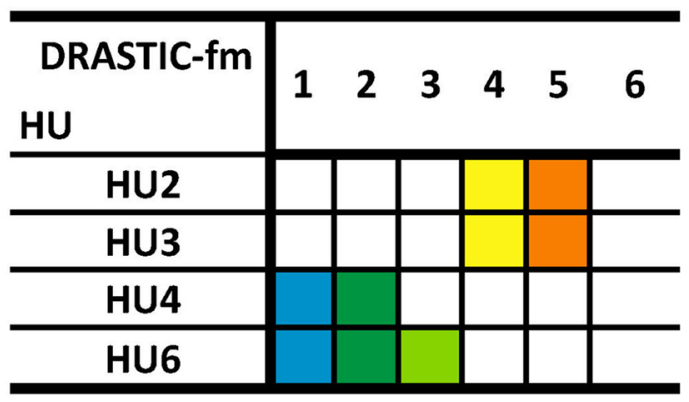

1- Low-Moderate; 2- Moderate; 3High; 4- High-Very high; 5- Very high; 6- Extreme

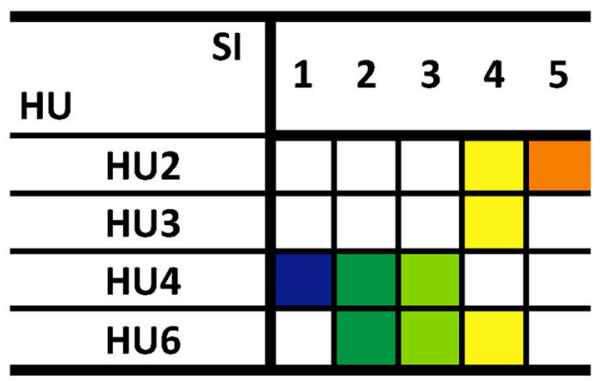

1- Very low-Low; 2- Low-Moderate;

3- Moderate-High; 4- High; 5- Very high

Fig. 8 Matrix of hydrogeological units and each of four potential groundwater vulnerability indexes for contamination in the urban catchment basins of Ribeira da Granja and Massarelos (Porto city, NW Portugal)

hydrogeomorphological and impervious materials features. Urban groundwater is a vital resource for many human activities and drinking purposes; this is facing threats due to the growing water demand coupled with decreasing water availability and increased contamination/pollution (e.g. [66-68]).

The sustainable development and management of groundwater resources requires the application of modern principles, methodologies and techniques related to groundwater science. Thus, studies using hydrogeomorphological techniques, remote sensing and GIS mapping (e.g., $[3,4,13,36,54,61,62])$ support a clear identification of the urban areas with potential infiltration zones. Consequently, that approach addresses an accurate understanding of recharge/discharge processes in urban areas [33]. In fact, urban areas are usually shaped with a complex underground and an intricate network of buried structures, galleries, channels, storm sewers, among others, as well as with impervious material surfaces. That underground framework is a central problem related to infiltration versus recharge/discharge $[9,72]$.
As stated before, IPI-Urban is a weighted sum of eight factors (through the AHP approach), namely hydrogeology, tectonic lineament density, slope, land use, drainage density, water supply network density, sewer network density and stormwater network density. The main factor maps is shown in the Figs. 9 and 10.

The Ribeira da Granja and Massarelos catchments have a dominant IPI-Urban (\%) included in the low-moderate categories: the average infiltration value is $47.4 \%$ for the Ribeira da Granja catchment and $43.9 \%$, for the Massarelos basin (Fig. 11). These IPI-Urban values highlight the importance of the parameter's hydrogeological units and land use. The high IPI-Urban category occurs where green urban areas coexist with hydrogeological units $\mathrm{UH} 2$ and UH3. Usually, the high IPI-Urban values occur in the valleys of streams, and also related to a high tectonic lineament density context.

The urban recharge was also evaluated. An initial recharge rate of $8 \%$ was considered and supported by regional hydrogeological studies of the Porto metropolitan area $[1,3,4]$, as well as with average annual rainfall 

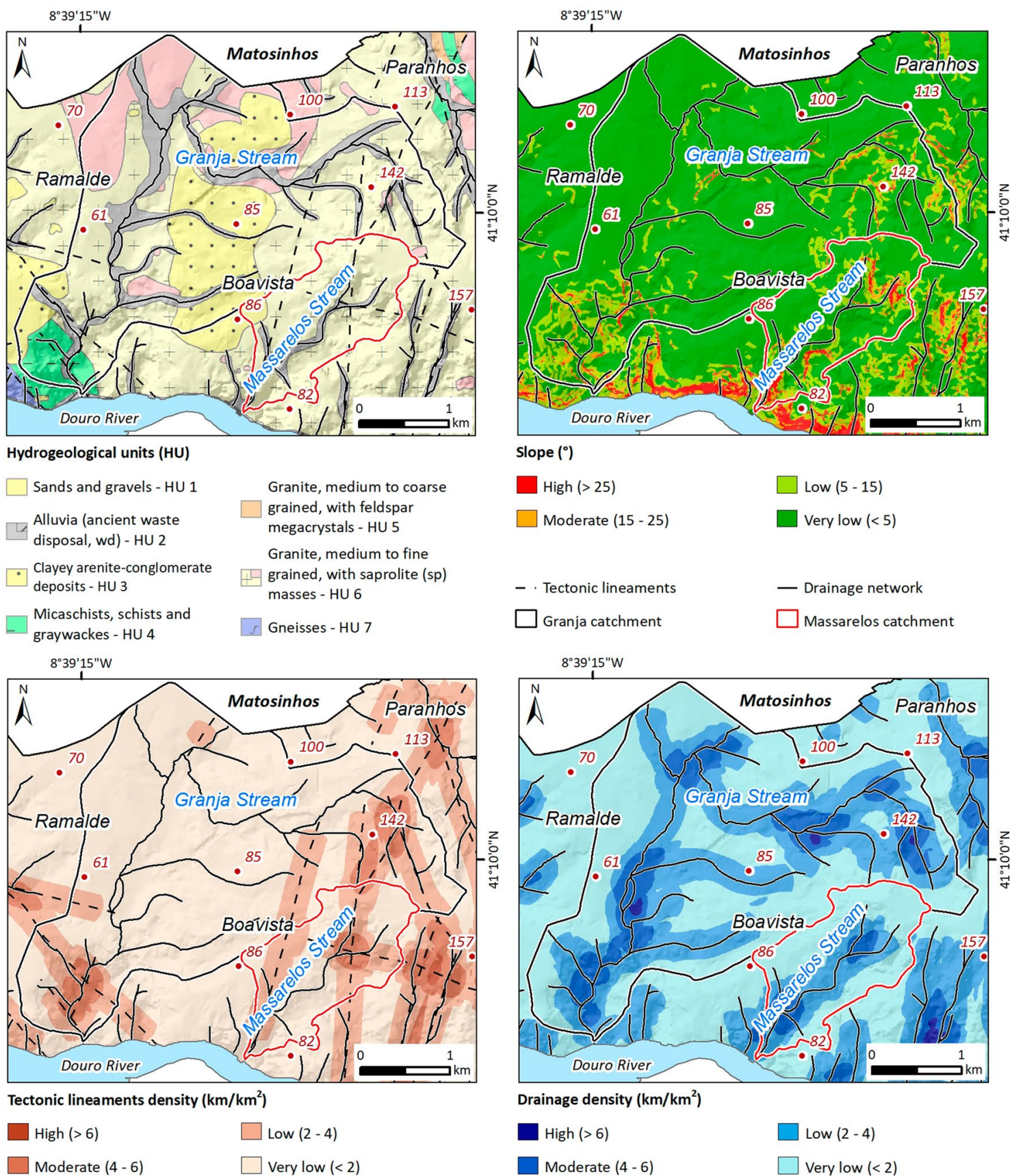

Fig. 9 Urban Potential Infiltration Index (IPI-Urban) in the urban catchment basins of Ribeira da Granja and Massarelos (Porto city, NW Portugal): hydrogeology, slope, tectonic lineament density and drainage density

data of $1071.7 \mathrm{~mm}$. The Ribeira da Granja and Massarelos catchments have an average recharge of $40.7 \mathrm{~mm} /$ year and $43.7 \mathrm{~mm} /$ year, respectively. The aquifer potential yields from the studied catchments have average values of $0.13 \mathrm{~L} / \mathrm{s} / \mathrm{km}^{2}$ and $0.12 \mathrm{~L} / \mathrm{s} / \mathrm{km}^{2}$, respectively.

\section{Urban groundwater conceptual site model: an integrative approach}

Selected catchment sites in Porto urban area 

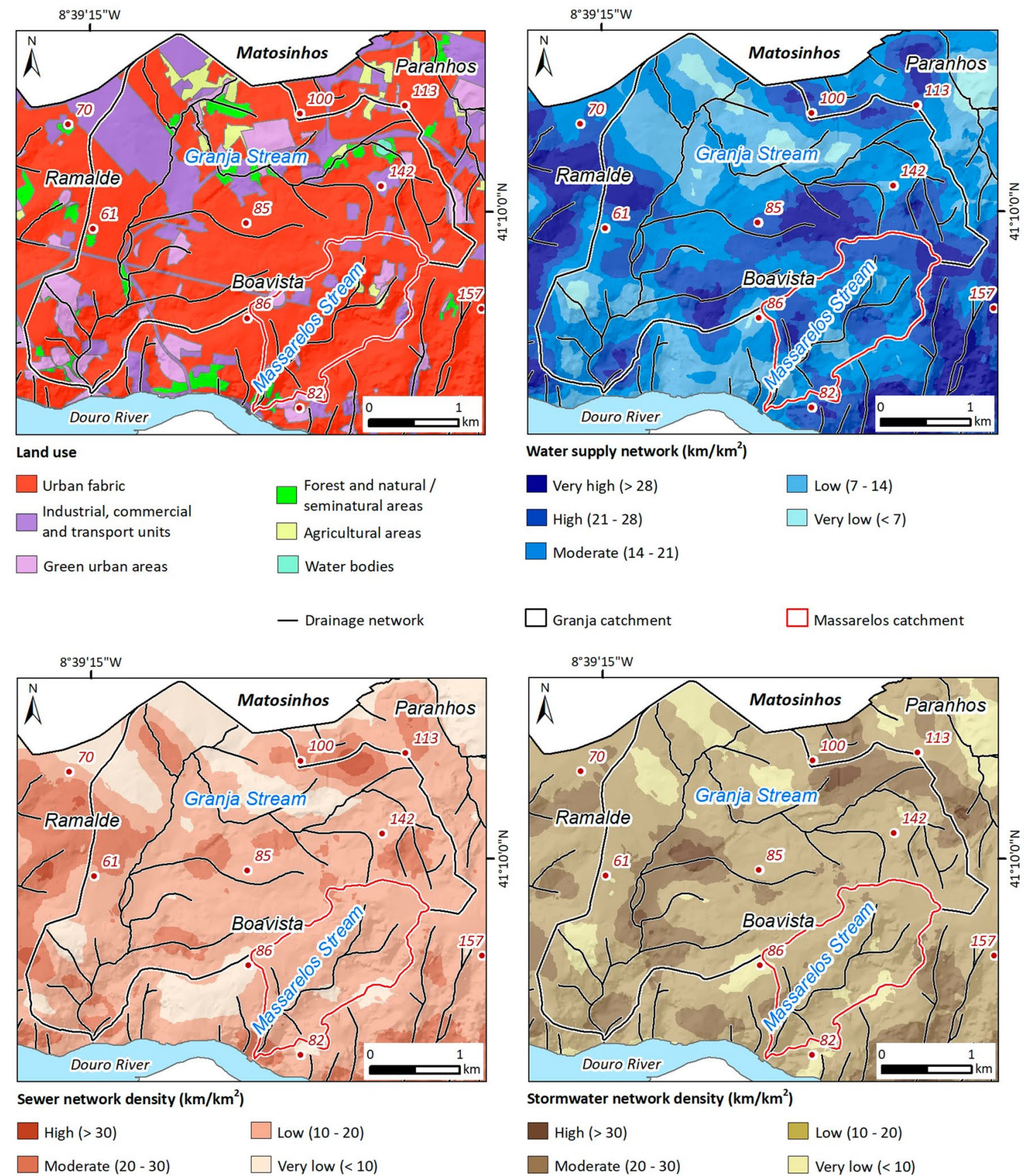

Fig. 10 Urban Potential Infiltration Index (IPI-Urban) in the urban catchment basins of Ribeira da Granja and Massarelos (Porto city, NW Portugal): land use, water supply network density, sewer network density and stormwater network density

demonstrate the importance of groundwater GIS-mapping for assessment of the urban water resources. Geovisualisation techniques and conceptualisation of urban groundwater systems must be grounded on earth-based site models to outline predicting scenarios.
Figure 12 shows the role of hydrogeomorphology mapping in the urban conceptual model for the studied catchments, with an area of $12.1 \mathrm{~km}^{2}$. This approach provided an interesting insight for the development of the urban groundwater systems conceptual site model. 

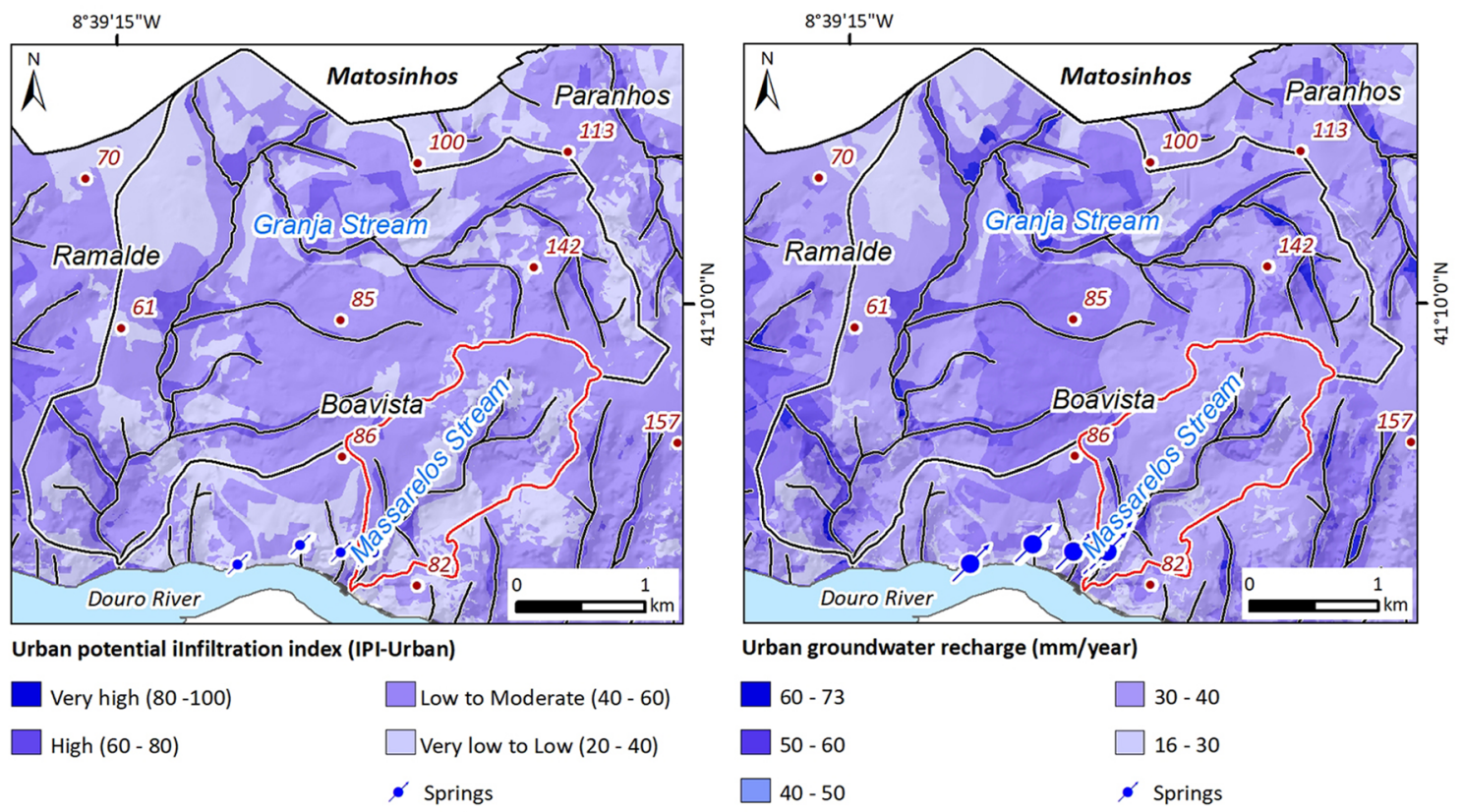

Urban groundwater recharge ( $\mathrm{mm} /$ year)

(60-73

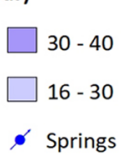

- Altitude (m)

— Drainage network

Granja catchment

Massarelos catchment

Fig. 11 Urban groundwater mapping in the urban catchment basins of Ribeira da Granja and Massarelos (Porto city, NW Portugal: urban potential infiltration index (IPI-Urban) and urban recharge

\section{Conclusions}

This work highlights the GIS-based mapping importance on urban groundwater systems. In addition, a detailed GISmapping study was performed in two key urban catchments (Porto city, NW Portugal). A comprehensive GIS analysis related to the urban groundwater was performed and an urban hydrology inventory survey and mapping were carried out. Lately, several urban inventories have been performed in the studied site, supported by field and desk techniques for urban groundwater and GIS-based mapping. The concept of the urban water cycle stresses an integrated approach to sustainable water resources management related to climatic, geological, physiographic, environmental, and sociocultural conditions that points out the key importance of an integrative assessment for urban groundwater resources. In addition, the approach must be grounded in balanced GIS earth-based models to better contribute to the design of the urban conceptual site models and understand the evolution of urban water systems.

Groundwater-related activities are significantly enhanced with the support of GIS-based analysis and hydrogeomorphological/hydrogeological mapping techniques for carrying out integrative sustainable urban management of water resources. The approach couple sustainable groundwater conservation and understanding of the urban hydrological cycle, revealing the comprehensive hydrological, ecological and societal functions of an urban landscape aiming for a balanced design with nature. 


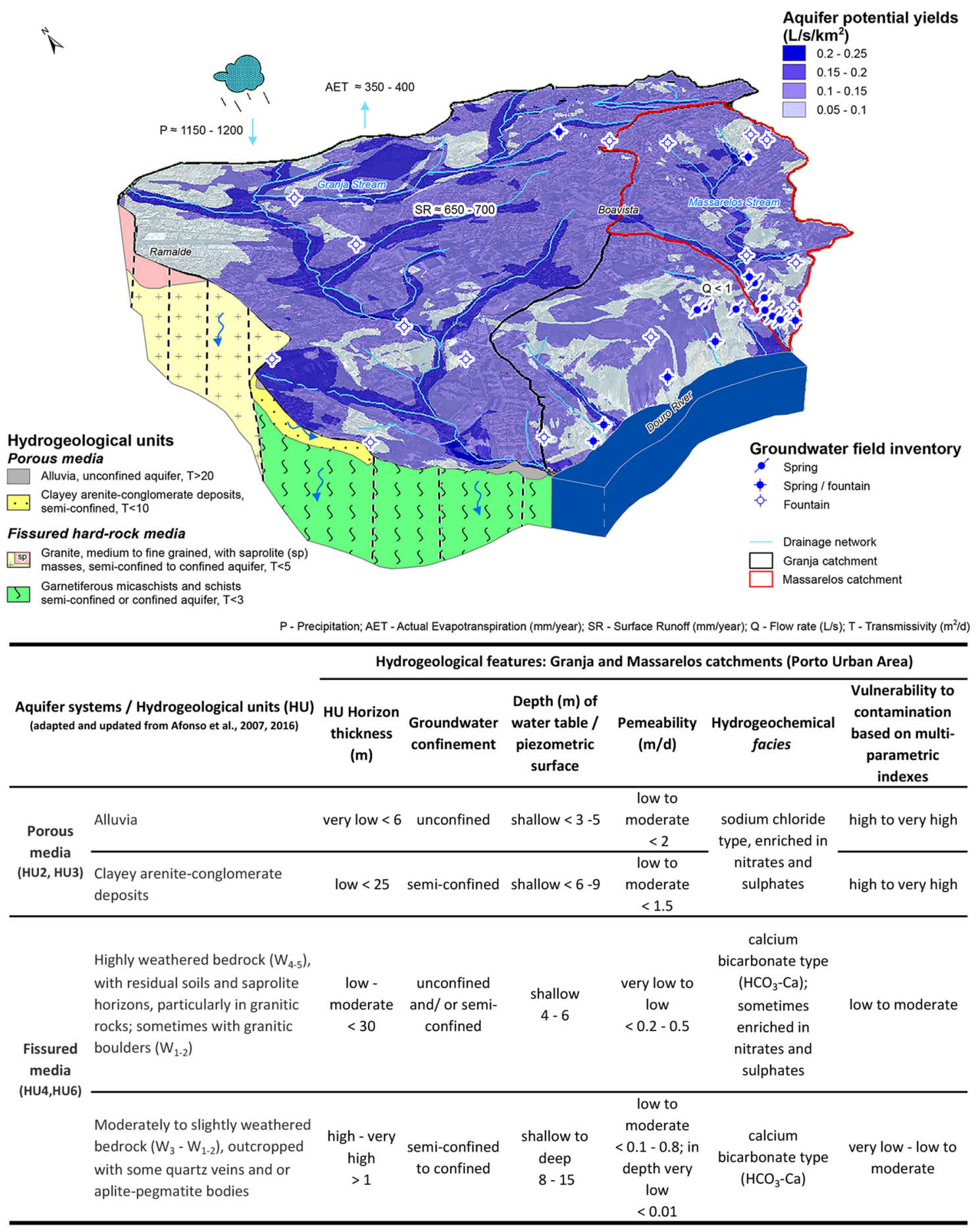

Fig. 12 Urban conceptual site model of the Ribeira da Granja and Massarelos catchments (Porto urban area, NW Portugal)

Acknowledgements This study was carried out partially under the framework of the LABCARGA|ISEP re-equipment program (IPPISEP|PAD'2007/08), Centre GeoBioTec|UA (UID/GEO/04035/2013), CITEUC (UID/Multi/00611/2013) and LRN|UC. The research was also funded by a doctoral scholarship from the Portuguese Foundation for Science and Technology (FCT) to L. Freitas (SFRH/BD/117927/2016). Special thanks are due to colleagues M.J. Afonso, J.M. Carvalho, C.
Delerue-Matos and R.L. Nagano for their input in some stages of the research. We thank the anonymous reviewers for their constructive and detailed comments, which helped to improve the clarity of the manuscript.

Authors' contributions This paper is based on the first author's Ph.D. thesis. Liliana Freitas and Helder I. Chaminé designed the research. 
Liliana Freitas performed the hydrological field inventories under the guidance of Helder I. Chaminé. Alcides J.S.C. Pereira and Helder I. Chaminé gave input on the fields of remote sensing, morphotectonics, regional geology and GIS mapping of the study sites. All authors contributed to the data analysis, interpretation and discussed results. Liliana Freitas and Helder I. Chaminé wrote the manuscript with contributions of all authors.

\section{Compliance with ethical standards}

Conflict of interest No potential conflict of interest was reported by the authors.

\section{References}

1. Afonso MJ, Chaminé HI, Carvalho JM, Marques JM, Gomes A, Araújo MA, Fonseca PE, Teixeira J, Marques da Silva M, Rocha $F$ (2007) Urban groundwater resources: a case study of Porto City in northwest Portugal. In: Howard KWF (ed) Urban groundwater: meeting the challenge. International association of hydrogeologists selected papers SP8. Taylor \& Francis Group, London, pp 271-287

2. Afonso MJ, Chaminé HI, Moreira PF, Marques JM (2010) The role of hydrogeotechnical mapping on the sustainable management of urban groundwater. In: Williams AL, Pinches GM, Chin CY, McMorran TJ, Massey Cl (eds) Proceedings of the 11 th congress of the international association for engineering geology, IAEG'2010, geologically active. CRC Press: Taylor \& Francis Group, Auckland, New Zealand, pp 595-1602

3. Afonso MJ, Freitas L, Chaminé HI (2019) Groundwater recharge in urban areas (Porto, NW Portugal): the role of GIS hydrogeology mapping. Sustain Water Resour Manag 5(1):203-216. https://doi.org/10.1007/s40899-019-00302-9

4. Afonso MJ, Freitas L, Pereira AJSC, Neves L, Guimarães L, Guilhermino L, Mayer B, Rocha F, Afonso MJ, Chaminé HI (2016) Environmental groundwater vulnerability assessment in urban water mines (Porto, NW Portugal). Water 8:499. https ://doi.org/10.3390/w8110499

5. Aller L, Bennet T, Lehr JH, Petty RJ (1987) DRASTIC: a standardized system for evaluating groundwater pollution potential using hydrologic settings. US EPA report, 600/2-87/035, Robert S. Kerr Environmental Research Laboratory, Ada, OK

6. Almeida A (2006) Geology and urban landscape: the granite in Oporto, NW Portugal. Eur Geol J 21(1):4-8

7. Antunes LN, Ghisi E, Thives LP (2018) Permeable pavements life cycle assessment: a literature review. Water 10:1575. https ://doi.org/10.3390/w10111575

8. Arulbalaji P, Padmalal D, Sreelash K (2019) GIS and AHP techniques based delineation of groundwater potential zones: a case study from Southern Western Ghats, India. Sci Rep 9:2082. https://doi.org/10.1038/s41598-019-38567-x

9. Attard G, Winiarski T, Rossier Y, Eisenlohr L (2016) Review: impact of underground structures on the flow of urban groundwater. Hydrogeol J 24:5-19. https://doi.org/10.1007/ s10040-015-1317-3

10. Babar M (2005) Hydrogeomorphology: fundamentals, applications and techniques. New India Publishing Agency, New Delhi

11. Babendererde S, Hoek E, Marinos P, Cardoso AS (2004) Characterization of granite and the underground construction in metro do Porto, Portugal. In: Viana da Fonseca A, Mayne PW (eds) Proceedings ISC-2 on geotechnical and geophysical site characterization, vol 1. Mill Press, Rotterdam, pp 39-48
12. Bandarin F, van Oers R (2015) Reconnecting the city: the historic urban landscape approach and the future of urban heritage. Wiley Blackwell, London

13. Barroso MF, Ramalhosa MJ, Olhero A, Antão MC, Pina MF, Guimarães L, Teixeira J, Afonso MJ, Delerue-Matos C, Chaminé $\mathrm{HI}$ (2015) Assessment of groundwater contamination in an agricultural peri-urban area (NW Portugal): an integrated approach. Environ Earth Sci 73(6):2881-2894. https://doi. org/10.1007/s12665-014-3297-3

14. Begonha A, Sequeira Braga MA (2002) Weathering of the Oporto granite: geotechnical and physical properties. CATENA 49:57-76. https://doi.org/10.1016/S0341-8162(02)00016-4

15. Brunelli M (2015) Introduction to the analytic hierarchy process. SpringerBriefs in operations research. Springer, Berlin

16. Carríngton da Costa J (1938) O Pôrto: geografia-geologia. In: Bastos C (org.), Nova Monografia do Porto, Companhia Portuguesa Editora, Porto, pp 3-32

17. Castany G, Margat J (1965) Les cartes hydrologiques: essai de définition. Bull Int Assoc Sci Hydrol 10(1):74-81. https://doi. org/10.1080/02626666509493375

18. Cascelli E, Crestaz E, Tatangelo F (2012) Cartography and geovisualization in groundwater modelling. In: Borruso G, Bertazzon S, Favretto A, Murgante B, Torre CM (eds) Geographic information analysis for sustainable development and economic planning. New Technologies, IGI Global, Hershey, pp 49-67

19. Chaminé HI (2015) Water resources meet sustainability: new trends in environmental hydrogeology and groundwater engineering. Envirorn Earth Sci 73(6):2513-2520. https://doi. org/10.1007/s12665-014-3986-y

20. Chaminé $\mathrm{HI}$, Afonso MJ, Freitas L (2014) From historical hydrogeological inventories, through GIS mapping to problem solving in urban groundwater systems. Eur Geol J 38:33-39

21. Chaminé HI, Carvalho JM, Teixeira J, Teixeira J (2015) Role of hydrogeological mapping in groundwater practice: back to basics. Eur Geol J 40:34-42

22. Chaminé HI, Teixeira J, Pires A, Silva RS, Pinho T, Monteiro R, Costa AL, Abreu T, Trigo JF, Afonso MJ, Carvalho JM (2016) From engineering geosciences mapping towards sustainable urban planning. Eur Geol J 41:16-25

23. Chaminé $\mathrm{HI}$, Afonso MJ, Robalo PM, Rodrigues $\mathrm{P}$, Cortez C, Monteiro Santos FA, Plancha JP, Fonseca PE, Gomes A, Devy-Vareta NF, Marques JM, Lopes ME, Fontes G, Pires A, Rocha F (2010) Urban speleology applied to groundwater and geo-engineering studies: underground topographic surveying of the ancient Arca D’Água galleries catchworks (Porto, NW Portugal). Int J Speleol 39(1):1-14. https://doi.org/10.5038/1827-806X.39.1.1

24. Chaminé HI, Gama Pereira LC, Fonseca PE, Noronha F, Lemos de Sousa MJ (2003) Tectonoestratigrafia da faixa de cisalhamento de Porto-Albergaria-a-Velha-Coimbra-Tomar, entre as Zonas Centro-Ibérica e de Ossa-Morena (Maciço Ibérico, W de Portugal). Cad Lab Xeol Laxe 28:37-78

25. Civita MV (2010) The combined approach when assessing and mapping groundwater vulnerability to contamination. J Water Resour Prot 2:14-28. https://doi.org/10.4236/jwarp.2010.21003

26. Cloots-Hirsch A-R, Tricart J (1978) L'eau, facteur écologique de I'aménagement: I'exemple de I'Alsace. Rev Géogr Lyon 53(4):339-354. https://doi.org/10.3406/geoca.1978.1235

27. COBA - Consultores de Engenharia e Ambiente SA (2003) Carta geotécnica do Porto. $2^{\text {a }}$ edição, COBA/FCUP/CMP, Porto

28. Costa-Lobo M (1991) Oporto: city profile. Cities 8:38-43

29. de Oliveira Marques AH (1972) History of Portugal, from Lusitania to Empire, vol 1. Columbia University Press, New York

30. Denny SC, Allen DN, Journeay JM (2007) DRASTIC-Fm: a modified vulnerability mapping method for structurally controlled aquifers in the southern Gulf Islands, British Columbia, 
Canada. Hydrogeol J 15:483-493. https://doi.org/10.1007/s1004 0-006-0102-8

31. DGT - Direção-Geral do Território (2018) Especificações técnicas da carta de uso e ocupação do solo de Portugal continental para 1995, 2007, 2010 e 2015. Direção-Geral do Território, Lisbon (technical report)

32. Dykes J, Maceachren AM, Kraak M-J (2005) Exploring geovisualization. International Cartographic Association Elsevier, Oxford

33. Fenta AA, Kifle A, Gebreyohannes T, Hailu G (2015) Spatial analysis of groundwater potential using remote sensing and GISbased multi-criteria evaluation in Raya Valley, northern Ethiopia. Hydrogeol J 23:195-206. https://doi.org/10.1007/s1004 0-014-1198-x

34. Foster SD, Hirata R, Gomes D, D'Elia M, Paris M (2002) Groundwater quality protection: a guide for water utilities, municipal authorities, and environment agencies. The World Bank, Washington, DC

35. Freitas L, Afonso MJ, Devy-Vareta N, Marques JM, Gomes A, Chaminé HI (2014) Coupling hydrotoponymy and GIS cartography: a case study of hydrohistorical issues in urban groundwater systems, Porto NW Portugal. Geogr Res 52(2):182-197. https:// doi.org/10.1111/1745-5871.12051

36. Freitas L, Afonso MJ, Pereira AJSC, Delerue-Matos $C$, Chaminé $\mathrm{HI}$ (2019) Assessment of sustainability of groundwater in urban areas (Porto, NW Portugal): a GIS mapping approach to evaluate vulnerability, infiltration and recharge. Environ Earth Sci 78:140. https://doi.org/10.1007/s12665-019-8167-6

37. Garcia-Fresca B, Sharp JM (2005) Hydrogeologic considerations of urban development: urban-induced recharge. In: Ehlen J, Haneberg WC, Larson RA (eds) Humans as geologic agents. Reviews in engineering geology, vol XVI. The Geological Society of America, Boulder, pp 123-136

38. Gilbrich WH, Struckmeier WF (2014) 50 years of hydro(geo)logical mapping activities under the auspices of UNESCO, CGWM, IAH and BGR: a report. UNESCO, Paris

39. Guppy L, Uyttendaele P, Villholth KG, Smakhtin V (2018) Groundwater and sustainable development goals: analysis of interlinkages. UNU-INWEH Report Series, Issue 04. United Nations, University Institute for Water, Environment and Health, Hamilton, Canada

40. Hibbs BJ, Sharp JM (2012) Hydrogeological impacts of urbanization. Environ Eng Geosci 18(1):3-24. https://doi.org/10.2113/ gseegeosci.18.1.3

41. Howard KWF (2015) Sustainable cities and the groundwater governance challenge. Environ Earth Sci 73(6):2543-2554. https://doi. org/10.1007/s12665-014-3370-y

42. IHP - International Hydrological Programme (2017) IHP-VIII water security-responses to local, regional, and global challenges (2014-2021): themes and focal areas. UNESCO, Division of Water Sciences, Paris

43. INE - Instituto Nacional de Estatística (2011) Statistical information about Portuguese population: Porto city. http://www.ine.pt/. Accessed Oct 2018

44. Jaiswal RK, Mukherjee S, Krishnamurthy J, Saxena R (2003) Role of remote sensing and GIS techniques for generation of groundwater prospect zones towards rural development: an approach. Int J Remote Sens 24(5):993-1008. https://doi.org/10.1080/01431 160210144543

45. Jha MK, Chowdhury A, Chowdary V, Peiffer S (2007) Groundwater management and development by integrated remote sensing and geographic information systems: prospects and constraints. Water Resour Manag 21(2):427-467. https://doi.org/10.1007/ s11269-006-9024-4

46. Kaushal SS, McDowell WH, Wollheim WM, Johnson TAN, Mayer PM, Belt KT, Pennino MJ (2015) Urban evolution: the role of water. Water 7(8):4063-4087. https://doi.org/10.3390/w7084063

47. Kim G-B, Ahn J-S, Marui A (2009) Analytic hierarchy models for regional groundwater monitoring well allocation in Southeast
Asian countries and South Korea. Environ Earth Sci 59:325-338. https://doi.org/10.1007/s12665-009-0029-1

48. Kresik N, Mikszewski A (2013) Hydrogeological conceptual site models: data analysis and visualization. CRC Press, Boca Raton

49. Lerner DN (2002) Identifying and quantifying urban recharge: a review. Hydrogeol J 10:143-152. https://doi.org/10.1007/s1004 0-001-0177-1

50. Malczewski J, Rinner C (2015) Multicriteria decision analysis in geographic information science. Springer, New York

51. Margat J, van der Gun J (2013) Groundwater around the world: a geographic synopsis. CRC Press, Boca Raton

52. Marsalek J, Jimenez-Cisneros B, Karamouz M, Malmquist PA, Goldenfum J, Chocat B (2008) Urban water cycle processes and interactions. UNESCOHP Urban water series. Taylor and Francis, Leiden

53. Mu E, Pereyra-Rojas M (2017) Understanding the analytic hierarchy process. SpringerBriefs in operations research. Springer, Cham

54. Nag SK, Saha S (2014) Integration of GIS and remote sensing in groundwater investigations: a case study in Gangajalghati block, Bankura district, West Bengal, India. Arab J Sci Eng 39:5543-5553. https://doi.org/10.1007/s13369-014-1098-3

55. Nas B, Berktay A (2010) Groundwater quality mapping in urban groundwater using GIS. Environ Monit Assess 60:215-227. https ://doi.org/10.1007/s10661-008-0689-4

56. Ribeiro L, Pindo JC, Dominguez-Granda L (2017) Assessment of groundwater vulnerability in the Daule aquifer, Ecuador, using the susceptibility index method. Sci Total Environ 574:1674-1683. https://doi.org/10.1016/j.scitotenv.2016.09.004

57. Saaty TL (2012) Decision making for leaders: the analytic hierarchy process for decisions in a complex world, 3rd edn. RWS Publications, Pittsburgh

58. Schirmer M, Leschik S, Musolff A (2013) Current research in urban hydrogeology: a review. Adv Water Resour 51:280-291. https:// doi.org/10.1016/j.advwatres.2012.06.015

59. Şener E, Davraz A (2013) Assessment of groundwater vulnerability based on a modified DRASTIC model, GIS and an analytic hierarchy process (AHP) method: the case of Egirdir Lake basin (Isparta, Turkey). Hydrogeol J 21:701-714. https://doi.org/10.1007/s1004 0-012-0947-y

60. Struckmeier WF, Margat J (1995) Hydrogeological maps: a guide and a standard legend. International Association of Hydrogeologists, Hannover

61. Teixeira J, Chaminé HI, Carvalho JM, Pérez-Alberti A, Rocha $F$ (2013) Hydrogeomorphological mapping as a tool in groundwater exploration. J Maps 9(2):263-273. https://doi.org/10.1080/17445 647.2013.776506

62. Teixeira J, Chaminé HI, Espinha Marques J, Carvalho JM, Pereira AJ, Carvalho MR, Fonseca PE, Pérez-Alberti A, Rocha F (2015) A comprehensive analysis of groundwater resources using GIS and multicriteria tools (Caldas da Cavaca, Central Portugal): environmental issues. Environ Earth Sci 73:2699-2715. https://doi.org/10.1007/ s12665-014-3602-1

63. Tricart J (1961) Géomorphologie et eaux souterraines. IAHS, Red Book Series (56), pp 22-27

64. Tricart J, Cloots-Hirsch A-R, Griesbach JC (1965) Géomorphologie et eaux souterraines dans le bassin de Santiago du Chili. Bull Fac Lett Strasbg 43(7):605-674

65. Tubau I, Vázquez-Suñé E, Carrera J, Valhondo C, Criollo R (2017) Quantification of groundwater recharge in urban environments. Sci Total Environ 592:391-402. https://doi.org/10.1016/j.scito tenv.2017.03.118

66. UN - United Nations (2015) Transforming our world: the 2030 Agenda for sustainable development. United Nations, New York

67. UN - United Nations (2018) Tracking progress towards inclusive, safe, resilient and sustainable cities and human settlements. United Nations, SDG 11 synthesis report, high level political forum 2018. Nairobi, Kenya. https://doi.org/10.18356/36ff830e-en 
68. UN-Water (2016) Water and sanitation interlinkages across the 2030 agenda for sustainable development. United Nations, Geneva

69. Vázquez-Suñé E, Carrera J, Tubau I, Sánchez-Vila X, Soler A (2010) An approach to identify urban groundwater recharge. Hydrol Earth Syst Sci 14:2085-2097. https://doi.org/10.5194/ hess-14-2085-2010

70. Vrba J, Verhagen BTh (2011) Groundwater emergency situations: a methodological guide. In: IHP-VII series on groundwater no. 3, International Hydrological Programme, Division of Water Sciences, UNESCO, Paris

71. Vrba J, Zaporozec A (1994) Guidebook on mapping groundwater vulnerability. In: International Association of Hydrogeologists ICH 16. Verlag Heinz Heise, Hannover

72. Wiles TJ, Sharp JM (2008) The secondary permeability of impervious cover. Environ Eng Geosci 14(4):251-265. https://doi. org/10.2113/gseegeosci.14.4.251
73. Yeh H-F, Lee C-H, Hsu K-C, Chang P-H (2009) GIS for the assessment of the groundwater recharge potential zone. Environ Geol 58:185-195. https://doi.org/10.1007/s00254-008-1504-9

74. Zaporozec A (ed) (2004) Groundwater contamination inventory: a methodological guide with a model legend for groundwater contamination inventory and risk maps. In: UNESCO, IHP-VI, series on groundwater, 2. UNESCO, Paris

Publisher's Note Springer Nature remains neutral with regard to jurisdictional claims in published maps and institutional affiliations. 